\title{
Elements and value-added of a human security approach in the study of climate change
}

Des Gasper - February 2013

\section{What can human security analysis add in the study of climate change?}

To present climate change as an issue of human security means to focus on the impacts and implications in the lives of ordinary people, not only in the agendas of armies, states or national economies. It means, for example, looking at life expectancies and patterns of nutrition, morbidity and mortality, not only at whether stressed populations might explode into armed conflict - the extreme 'Darfur' scenario. That sort of scenario and such preoccupations often reflect traditional state-centred and military-focused concerns more than person-focused ones. That poor people in most cases seem to lack the organization, cohesion or resources to initiate armed conflict does not mean that their plight is not an issue of-human-security. As part of a humanist perspective, the human security approach means looking at more also than aggregates of monetized economic variables, but rather at the contents, objective and subjective, of the lives of all of the people - at their 'do-ings' and 'be-ings', the constraints that they face, the real opportunities that they have, or lack, and the meanings that they experience - not only at the parts and the persons that are counted in money terms.

Security language is commonly tacitly oriented to prioritising and safeguarding the interests of powerful groups within nation-states. 'Human security' is in origin a counter-concept, that attempts to turn the frequently predominant implicit association of 'security' with the security of the state, to a focus instead on the security of human persons, seen as real individuals in the round, and not only as bodies and statistics. The attempted turn involves, first, looking at the security of distinct human individuals, in the circumstances of their particular lives at the intersection of many different forces. Why focus on this set, human persons? Why not ignore some of them? Or why not also include the security of bacteria, algae or clouds? Evidently, human security thinking is a humanist approach, sister to the perspectives of human rights and human development; better put, it is a sister face of a humanist perspective. Further, with all human individuals taken as the set of primary objects of value concern, there is implicitly or typically an interest in the security of the human species, including future generations. According to some authors, there should also be a concern with the security in some respects of human groups, cultures and meaning-systems, since persons are group members (see e.g. Roe 2010). Securing one thing (such as a group) may, however, sometimes be in competition with securing others (such as individual persons). Different types of human security approach reflect different stances on how to conceptualise human identity, human interests, and how to weigh competing considerations. In effect there are different viewpoints about the nature of being human. 
While there has been enormous discussion of the meanings of 'security', which is the term whose meaning a 'human security' approach attempts to turn away from a state-centred presumption, there has been too little attention in much of the work on human security to thinking about the meaning of 'human' and thus to what supposedly is to be secured, in addition to bare life. Yet, since 'security' is fundamentally a prioritising term, rather than an entity in itself, the main focus should be on what is being secured and why. So human security analysis must be led to engage with the central issues of what it is to be human, and what are and/or should be priorities. It connects here to earlier and ongoing work in basic human needs analysis (e.g. Burton 1990) and to traditions of exploration in humanist philosophy.

Being human involves more than having sufficient food and other basic items in order to survive. Humans are embodied, and, not least, gendered; they are not only mortal but have a lifecycle, of growth, maturity and decline. The long period of growth involves enormous enculturation, acquisition of attitudes, knowledge and skills that are not genetically encoded but instead socially constructed, communicated, inculcated and adapted, and that build on our latent capacities, including those for reasoning and choice. Humans desire to employ their capacities, in some degree, to exercise agency. These capacities are a key focus in recent human security theory, in the concept of 'securitability': the ability of people to establish and maintain their own security (UNDP 2003). Perhaps related to the long periods of dependence in the life cycle, human identity and functioning are intensely social and relational; people do not become human in isolation. Nor are they human in the abstract: our physical, felt presence is in a particular time, place and social setting. Humans have complex systems of emotions which mediate their dependencies and help to mobilize and orient their agency. Security and insecurity are matters both of objective vulnerability and of emotional state and subjective perception (Leaning 2008; Leaning et al., 2004). Put differently, vulnerability is not only physical but emotional and, more broadly, existential.

Overall, the intersecting multiplicity of their life circumstances-their physical location, personal capacities, health, gender, social status and enculturation, assets and options, habits and perceptions, relationships and exposure-determines people's security and insecurity. So for example: 'In the 2007 Cyclone Sidr [in Bangladesh] some people died who declined to go to shelters because that would leave their animals unattended, since some who went to shelters during a previous warning were robbed at home.' (Saferworld 2008: p.iii).

Studying the determinants of real people's insecurity requires holistic thinking at the level of individual lives - a narrative approach, that studies people's historically determined situation and constrained agency-and holistic thinking at the level of grander systems, about the socioeconomic drivers of some people's marginalization in their own countries and the drivers of economic, environmental and climate change at a global scale (Gasper 2010, 2013a). This combination of, first, empathetic detailed attention to specific local vulnerabilities and, second, bold but cool attention to global interconnections, including to linkages that frequently generate costs-ecological, medical, psychological, cultural, economic costs-for other people, costs that are ignored in narrowly national, disciplinary, or commercial calculations, was well articulated by Denis Goulet, for example in The Cruel Choice (Goulet, 1971; Gasper 2011). His work on 'development 
ethics' consciously proceeded in the spirit articulated in the 1940s by the French movement 'Économie et Humanisme': that we should consider 'le développement de tout l'homme et de tous les hommes'. The Cruel Choice was one of the major precursors of the wave of human security thinking that has unfolded since around 1990; its second chapter, for example, was entitled "Vulnerability: the key to understanding and promoting development".

Goulet made clear that the required combination of types of analysis is unlikely to happen in the absence of a certain perceptual and emotional base. It is not a free-floating technical instrument. As mentioned earlier, why, for example, should we not otherwise leave out some (even most) humans from our field of attention and concern? In cases where we do not fear them (or their successors) or hope to gain from them, conventional security analyses leave them out. Dalby remarks in his chapter in this book that the conventional formulation of security corresponds to the Westphalian era of competing nation-states and includes the stabilization of the operating environments required for smooth running of commercial society within and across national boundaries.

Human security analysis does consider closely the nexuses between deprivation and insecurity on the one hand and violence and crime and migration on the other. But its interest in people everywhere extends beyond self-interest and fear about what they might do. It shares the humanist values expressed by the human rights tradition, and does not look only at other people and their difficulties when they are feared, but fundamentally because they are respected and valued as fellow humans. Human rights are an essential element in a human security approach. Arguably though, a human security approach adds something that has not been well developed in mainstream human rights work: an ontological perspective of interconnectedness (Gasper 2012, 2013a). The combination of this with a human rights style concern for the dignity of every person is central, for the motivation for tracing the connections across national, disciplinary and organizational boundaries rests in part on sympathetic interest in fellow humans' lives around the globe.

For climate change analyses this means close attention to identifying how particular people, in particular life-niches, are affected and how they might be able to respond: for example, 'rural communities in Bangladesh, farmers in Ethiopia and slum dwellers in Haiti' (UNDP 2007:3), in the words of the Human Development Report 2007/8 on climate change. Citing human rights criteria, this Report proceeded partly in the spirit of a human security approach, repeatedly invoking the interests of particular vulnerable groups, including children, 'our children and grandchildren' (p.2), and 'future generations'. In contrast, the counterpart report on climate change from the World Bank, the World Development Report 2010 (World Bank 2010; WDR) barely mentions children and never once uses the terms 'grandchildren' or 'future generations' (Gasper et al., 2013a). It focuses on abstract aggregates, especially money aggregates. Sadly, the successor Human Development Report (HDR) 2011 on environmental sustainability almost completely abandons the substantive human language and corresponding focus of the 2007/8 HDR (see Gasper et al., 2013b). It retreats instead to the virtually useless hyper-aggregated category of a global Human Development Index (UNDP 2011: 2), which conceals the implications of climate change for the poorest groups. An 
aggregated index like the HDI sums achievements for all inhabitants of a country or region--in this case the world--and conceals the scale of impacts on poor people, many of whom may fare far worse than the national or regional average, and even more so in the case of a global average. A human security approach aims to do the opposite, and to reveal and to respond to these people's situations.

We will start with a case, that of Bangladesh; then essay a specification of key dimensions and components in a human security approach; and discuss its application and potential valueadded in the study of climate change, including through use of a scenarios methodology for identifying, appreciating and responding to future threats and opportunities.

\section{Bangladesh: which threats to which values and which persons?}

...the level of insecurity relating to 'freedom from fear' is perceived as being relatively low compared to 'freedom from want'. Bangladeshis consider issues such as poverty, employment, food security and health to be much greater concerns than crime. (Saferworld 2008, p.104.) In a survey of 2000 households in Bangladesh, undertaken by the Research Division of BRAC, the largest development NGO in Bangladesh and perhaps the world, many more people identified 'freedom from want' issues as big problems--poverty (69 per cent), unemployment (65 percent), provision of utilities (56 percent) and vulnerability to natural disasters (51 percent)--than wished to highlight issues conventionally placed under a 'freedom from fear' heading (including crime, extortion, and availability of firearms). Crime was rated as one of the five main concerns by only about one third of the sample.

'With 50 percent of Bangladeshis living below the poverty line, poverty and unemployment are the greatest concerns for most people. Poverty underlies many other problems. It is a major cause of food insecurity, since many people lack the resources (including land and agricultural products) either to grow their own food or to buy it from others. Limited resources make it harder to access basic services such as healthcare, sanitation and education. Poverty and unemployment are also seen as being the two most important drivers of crime and injustice.' (Saferworld 2008: p.ii)

Similarly, when the interviews moved on from the priority values that are considered in jeopardy, to which sources of threat made people feel insecure:

'[n]atural disasters were the most common concern ( 53 percent), followed closely by a lack of healthcare (48 percent). The third most popular answer was a perceived increase in crime (28 percent), and fourth was drug abuse (23 percent). Worries about natural disasters are a much greater concern in rural areas [ 58 percent in rural areas, versus 37 percent in urban areas],... where the two most frequent responses are crime and drug abuse.' (Saferworld 2008: p.ii) In the period 1900-2008, sixty-six recorded cyclones caused on average over 9000 deaths (p.21). In 1970, apart from Cyclone Bhola's direct impact the resultant surge inland of sea waters killed approaching half a million people in total. 'Natural disasters' frequently have a large human component, in terms first of their causation and second of the determinants of the extent and distribution of their impacts. This principle probably applies with respect to causation of the two 
main such threats in Bangladesh, cyclones and floods, though the causes lie largely outside Bangladesh; and certainly the principle applies with regard to determinants of their impacts.

Interestingly, even when people were asked about the providers of security in relation to freedom from fear, the leading responses were not the conventional security apparatus: 'The five most popular answers were education institutions (43 percent), NGOs/micro-finance institutions (34 percent), [well above] police stations (28 percent), Union Parishads/municipalities (28 percent) and hospitals/healthcare facilities (20 percent). These results show that Bangladeshis understand human security to be about much more than crime and justice.' (Saferworld 2008, p.vii).

'Natural disasters' were thus already the greatest felt threat. Climate change is likely to seriously increase their frequency and magnitude. '...by some estimates, a one metre sea-level rise will submerge about one-third of the total area of Bangladesh, thereby uprooting 25-30 million of our people... They are most likely to become refugees of climate change', declared the head of government (Ahmed 2007). Even much smaller rises, and extreme weather events, could uproot large numbers of people.

'...urbanisation (or 'slumisation') would be likely to increase even more rapidly as desperate people moved towards the cities in search of work and food. This would further over-stretch already insufficient infrastructure and governance mechanisms... Secondly, there would likely also be much more emigration, in particular economic migration to India. This would be a very sensitive and possibly explosive political issue for both states;...' (Saferworld, 2008: 24).

'Despite this, little serious analysis is available of possible scenarios for the effects of climate change on human security in Bangladesh', at least as of a few years back, declared the Saferworld report (2008: xvi). This might reflect the sheer scale of the challenges faced, that exceed the capacity of business-as-usual politics, particularly the viciously divided party politics of Bangladesh. But in addition, the neglect reflects that the people at risk are predominantly the poorer groups, those on the lands most at risk of flooding, those with the least robust houses, those who feel they cannot risk to leave their animals unattended during a flood or cyclone.

\section{Dimensions and character of a human security approach}

Simon Dalby, in the preceding chapter in this book, reviews Rothschild (1995)'s list of four shifts or extensions proposed in human security and other 'non-traditional security' analyses: shifts away from the emphases adopted in state-centred and/or violence-centred security analyses. We noted earlier the first two, which both concern the conception of whose security: (1) downwards from the state to the human person, and (2) upwards from the state to the human species. Rothschild presents the latter in terms of the international system and the physical environment, but arguably in both these cases the ultimate object of security is the human species. Conceivably, security of all individuals equates to security of the species, but an explicit emphasis on the human species highlights the concern for those individuals who are as yet unborn.

We have touched also on the other two shifts, concerning: (3) security of which values, and which associated sectors (for example, food, water, physical and mental health); and (4) security 
through action by which providers. The extensions beyond the national state in this last case are both international and intra-national, including attention also to persons' self-provision and securitability. 'Securitability' is a concept coined for the Latvia Human Development Report 2003: 'the ability to avoid insecure situations and to retain a [psychological] sense of security when such situations do occur, as well as the ability to reestablish one's security and sense of security when these have been compromised' (UNDP: 2003, p.15).

The list can itself be usefully extended. Another dimension which Rothschild explored was: (5) Security as perceived by whom - the issue of so-called objective (expert-perceived) security versus subjective (self-perceived) security. Next, Oscar Gomez amongst others highlights three supplementary questions:- (6) Security against which threats, in the sense not merely of 'the threat of serious damage to priority value $\mathrm{V}$ ' but with regard to which specific types of event or force threaten to do that damage. Only because there are threats (at least felt threats) does security become an issue at all, but the threats that are perceived, considered relevant, and prioritised for attention vary considerably. (7) How much security - this point elaborates the third, concerning which values are to be secured, by asking: secured to what extent, what are the targets for the level of assurance. Last: (8) Secured by what instruments - this point elaborates the fourth, concerning who are the providers, with fuller attention now to the specific means that will be employed (Gomez et al. 2013). Table 1 encapsulates the checklist of questions and the corresponding agenda.

Table 1: Some features of human security discourse

\begin{tabular}{|c|c|}
\hline QUESTIONS/ISSUES & SOME EMPHASES/FEATURES IN HUMAN SECURITY DISCOURSE \\
\hline 1. Whose security? - I & $\begin{array}{l}\text { Human persons [and communities] not only bigger systems. Downwards shift } \\
\text { of focus, from the state }\end{array}$ \\
\hline 2. Whose security? - II & $\begin{array}{l}\text { Human species, not only national systems. Upwards shift of focus from the } \\
\text { state, including to the physical environment that sustains human society }\end{array}$ \\
\hline $\begin{array}{l}\text { 3. Security of what } \\
\text { (which values / which } \\
\text { sectors)? }\end{array}$ & $\begin{array}{l}\text { In terms of sectors: focus on basic sectors. } \\
\text { The conventional list of Freedoms ('freedom from want', 'freedom from fear', } \\
\text { 'freedom from indignity'). } \\
\text { Meanings of human } \rightarrow \text { what priorities? } \rightarrow \text { bodily safety, health, ...., but also } \\
\text { beyond bare survival. } \\
\text { Securing of human rights } \\
\text { Securing of present levels? - a concern with stability in only some respects }\end{array}$ \\
\hline 4. Provision by whom? & $\begin{array}{l}\text { Securitability; empowerment and not only treatment. } \\
\text { The idea of a 'constellation of providers' (UNDP 2003). }\end{array}$ \\
\hline $\begin{array}{l}\text { 5. Security as perceived } \\
\text { by whom? }\end{array}$ & Both 'objective' and 'subjective' \\
\hline $\begin{array}{l}\text { 6. Security against what } \\
\text { threats? }\end{array}$ & $\begin{array}{l}\text { Not only against threats of physical violence. } \\
\text { Ontology of interconnection and Intersectionality. Nexuses. } \\
\text { Thresholds as danger points. }\end{array}$ \\
\hline 7. How much security? & $\begin{array}{l}\text { Within sectors: ensure attainment of at least basic levels. } \\
\text { To ensure capability (the potential to be secure), or to ensure functioning } \\
\text { (actual security)? } \\
\text { Principle of harm avoidance, and Precautionary principle. }\end{array}$ \\
\hline 8. By what instruments? & $\begin{array}{l}\text { Human rights } \\
\text { Prevention not only palliation } \rightarrow \text { use also diverse and unorthodox instruments. } \\
\text { Promoting securitability }\end{array}$ \\
\hline
\end{tabular}


So, associated with the re-orientation of the answer to 'whose security?' is a system of linked features (Gasper 2005, 2010, 2013b). We saw earlier that underlying this agenda are a humanist normative concern, an ontology of interconnectedness (see, e.g., Thomashow 2002), and a resulting perception of human lives as marked by a combination of capability and vulnerability. Diverse types of threat to priority values for particular persons and groups can arise out of their particular locations in intersected, interconnected systems of systems: climatic, ecological and epidemiological, economic, social and political.

We need to consider the perceptions which underlie choices in these various dimensions. In particular we should reflect on the significance of the term 'human', and correspondingly on the arguments in support of the priority claims implied by a 'security' label. One cannot reasonably merely assert priority via use of security language; one should have convincing reasons for it, including ideas about the nature of persons - the referent in human security claims - and about nexuses of interconnection, threats, thresholds and potential damage or even collapse. Let us look, for a majority of the questions, at some examples.

\section{Question 1: Security for whom? - Persons or 'the economy'? Persons or citizens?}

The World Development Report on climate change gives much attention to economic calculations of the costs of climate change, and the net returns to programs for mitigation and adaptation. It estimates modest potential GDP losses from global warming: 'a global average GDP loss of about 1 percent' (World Bank 2010: 5). The impact is more in low-income countries but even there it is not more than a year's foregone growth. The estimates were based on the conservative and now superseded IPCC 2007 Report's climate projections, but that is not the issue here. Our concern is the methodology of calculation, namely estimation of the possible aggregate direct monetary costs of damage. This ignores other human costs and the indirect impacts of changes in disease patterns and of social and political unrest, conflict and migration, such as suggested for example by the Darfur crisis. It aggregates the losses of some, who may be poor and driven into destitution, with the gains of others, who can be already affluent. And it values effects according to market prices that put very little weight on the lost housing, the lost livestock, and even the lost life of the marginal low-income rural resident in Darfur or Bangladesh. Correspondingly, after extended discussion of various economic modelling exercises along these lines, seeking to determine whether a scenario of 2, 2.5, 3 or 3.5 degrees rise in average global temperatures offers the best economic rate of return, the Report deals shockingly briefly with the expected deaths from business-as-usual economic expansion. 'And over 3 million additional people could die from malnutrition each year', declares a single sentence at the end of a paragraph in the Overview (World Bank 2010: 5). As Dalby observes in the previous chapter in this book, security as interpreted by ruling establishments has usually been about 'making particular forms of economic action flourish, ...not about protecting non-commercial modes of human life.'

In contrast, the Human Development Report 2007/8, also fully devoted to climate change, focused more on human impacts than on GDP: 'In terms of aggregate world GDP, these short term 
effects may not be large. But for some of the world's poorest people, the consequences could be apocalyptic.' (UNDP 2007: v). The Report makes clear how their lives can be broken and stunted. Overall, the World Development Report's considerably lesser sense of urgency in response to climate change reflects its preoccupation with monetary magnitudes and thus with the interests of people who have more resources to protect themselves from possible future stresses (Gasper et al., 2013a: 32).

A second vital contrast is between a human rights based concept of human security, which covers all affected persons, and an interpretation of 'citizen security' which excludes non-citizens. The concept of 'citizen security' has risen in prominence in and from literature in Spanish, including in Spain's post-Franco Constitution and in post-dictatorships Latin America of the past generation. It has been defined as "the personal, objective and subjective condition of being free from violence or from the threat of intentional violence or dispossession by others" (UNDP 2005: 14-15). The concept is prominent in various other National and Regional Human Development Reports (e.g. UNDP (2010), UNDP (2012)) and in the World Development Report 2011 on conflict (World Bank 2011). While the label's reference is close to the 'personal security' component in the 1994 HDR's seven-fold list, its use of 'citizen' rather than 'personal' may partly grow out of the tradition of thinking about security as stabilization of the operating environments for commercial society within a nation-state system and about people as 'citizen consumers within the boundaries of nation states' (Dalby 2009: 160). Yet commercial society has increasingly drawn in large groups of noncitizens to very many countries, where their human rights often are at risk (Edwards and Ferstman 2011; Truong and Gasper 2011); and fossil-fuel based economic development within the nationstate system now endangers the livelihoods of non-citizens worldwide and in generations to come.

\section{Question 2: Security for whom ? - II : The human species and future generations?}

If one does not focus on persons, then the issue of future generations may not arise: instead all discussion is in terms of abstractions and aggregates - the nation, the economy, the national economy, the state. If one does focus on persons then one will eventually note that many of the people affected by environmental change have no current voice, including because most of them are not yet born or are not yet adults. So the Human Development Report 2007/8 talks specifically and frequently of 'humanity', 'human community', 'the world's poor', 'our children', 'our children and grandchildren', 'future generations', 'the world's poor and future generations'.

The World Development Report 2010 avoids all such terms (see Table 2 in Gasper et al., 2013a). Its 11,000 word Overview never mentions even grandchildren or future generations. In comparison to the HDR 2007/8, the WDR devotes more time to discussion of an insurance rationale for investment in climate change mitigation and adaptation; insurance feels like a safely conservative technical economic language. But it presents the case for insurance with an unusual amount of tentativeness and hedging (Gasper et al., 2013a: 35). For in this context an insurance argument introduces an assumption of moral community, at some level or levels. Climate change insurance is largely for the benefit of future generations, worldwide, and thus mostly for people who live abroad. Even if the argument is that rich countries should invest now in the efforts of 
developing countries in climate change adaptation and mitigation, because this investment prevents future 'catastrophic risks' for all (World Bank 2010:9) there is a presumption of solidarity of the present day rich North with at least the future generations in the North. These ethical choices are hidden behind the World Bank's economic calculations; and unlike the Human Development Report Office it is not ready to bring them out for discussion.

\section{Question 3 - Securing which values?}

The conventional slogans-cum-labels in human security discourse for referring to priority values have been 'freedom from want', 'freedom from fear', and subsequently also 'freedom from indignity' (CHS 2003; IIHR n.d.). 'Freedom from hazard impact' (Brauch 2005) is sometimes mentioned as if it was a new category to add to this set, but it is better seen as a highlighting of one type of threat which might endanger the basic freedoms. Not every hazard impact-for example the damage in a cyclone to a billionaire's private vacation island castle-should be listed as a human security concern. The priority values are partly the basis of broad international consensuses, reflected in the major conventions on human rights and the Millennium Declaration, and are partly subject to further selection and specification through context-specific debate and negotiation. Thus the GECHS (Global Environmental Change and Human Security) research program defined human security as the capacity of individuals and communities to respond to threats to their social, human and environmental rights, and the UN Trust Fund for Human Security takes a similar line. They recognise that achievement of rights cannot be achieved instantly and all at once, and that interpretation and prioritization must occur in situ.

Some authors, often from a conventional security studies background, wish to exclude 'freedom from want' issues, let alone 'freedom from indignity', from the concept of human security, and in effect to limit it to bodily safety (see e.g. MacFarlane and Khong 2006). This is despite the frequently demonstrated greater importance-both objective and (as we saw for Bangladesh) subjective- of 'freedom from want', for promoting human life and for quality-adjusted life-years. In the context-specific prioritizations and choices of focus required in National Human Development Reports (NHDRs) on human security, a wide range of priority values have emerged for special consideration in the reports concerned (see Table 2). Some reports attempt a comprehensive mapping of major threats to basic values (e.g., the prominent Arab Countries report of 2009 and Latvia report of 2003); a second group can be called 'citizen security' or citizen safety reports and focus on crime and physical violence; a third group focuses on state-building, as an essential basis for human security, that demands priority in some cases; and the fourth group of reports chooses one or two other lead challenges felt in the particular country at that particular time (e.g., the Chile study of social modernization, and the African regional report on food security and human development). 
Table 2. Categorization of some of the National Human Development Reports that have explicitly adopted a human security theme. (Based on Gomez et al. 2013)

\begin{tabular}{|c|c|c|c|}
\hline $\begin{array}{c}\text { COMPREHENSIVE } \\
\text { FOCUS }\end{array}$ & \multicolumn{3}{|c|}{ NARROWER FOCUS } \\
\hline $\begin{array}{l}\text { Investigation of the } \\
\text { context-specific range } \\
\text { of primary threats to } \\
\text { primary values, done } \\
\text { without restriction in } \\
\text { terms of how to } \\
\text { organize security } \\
\text { provision }\end{array}$ & $\begin{array}{l}\text { Focus on one } \\
\text { priority set of } \\
\text { threatened } \\
\text { values: 'citizen } \\
\text { security', often } \\
\text { with main } \\
\text { attention given to } \\
\text { use of } \\
\text { conventional } \\
\text { security } \\
\text { instruments }\end{array}$ & $\begin{array}{l}\text { Focus on a priority } \\
\text { threatened } \\
\text { means: the State }\end{array}$ & $\begin{array}{l}\text { Focus on one or } \\
\text { two selected, } \\
\text { context-specific } \\
\text { threatened values } \\
\text { or primary threats, } \\
\text { without restriction } \\
\text { in terms of how to } \\
\text { organize security } \\
\text { provision }\end{array}$ \\
\hline $\begin{array}{l}\text { Comprehensive } \\
\text { mapping reports } \\
\quad \text { Arab Countries } \\
\quad \text { (2009) } \\
\text { Benin }(2011) \\
\quad \text { Djibouti 2012/13 } \\
\text { Kenya (2006) } \\
\text { Latvia (2003) } \\
\text { Thailand (2009) }\end{array}$ & $\begin{array}{ll}\text { 'Citizen security' } \\
\text { reports } \\
\text { Caribbean } \\
(2012) \\
\text { Costa Rica } \\
\text { (2005) } \\
\text { Philippines } \\
\text { (2005) } \\
\text { (Bangladesh } \\
2002)\end{array}$ & $\begin{array}{l}\text { State-building } \\
\text { reports } \\
\text { Afghanistan } \\
\text { (2004) } \\
\text { Democratic } \\
\text { Republic of } \\
\text { Congo (2008) } \\
\text { Occupied } \\
\text { Palestinian } \\
\text { Territories } \\
(2009 / 10)\end{array}$ & $\begin{array}{l}\text { Lead-challenge } \\
\text { driven reports } \\
\quad \text { Africa (2012) } \\
\text { Chile (1998) } \\
\text { Macedonia } \\
\text { (2001) } \\
\text { Mali (2009) } \\
\text { Senegal } \\
\text { (2010) } \\
\text { Uruguay } \\
2012 / 13\end{array}$ \\
\hline
\end{tabular}

Various other NHDRs have addressed climate change (e.g. Kazakhstan 2008, Moldova 2009/10, Cambodia 2011) and could also be viewed as part of this fourth group. Barnett et al. (2010: 20) underline that this sort of prioritization, using the name of 'security'

to prioritize individual and community needs, rights, and values at risk from environmental change also engages diverse policy communities, including those concerned with development policies, sustainable development policy, human rights, and foreign policy. Thus the meaning of "human security" is not left to the traditional purveyors of security and is instead continually negotiated in ways that are far less likely to justify the strengthening of the state at the expense of human security.

Some discussions of human security - for example after the Asian financial crisis of 199798-have emphasised stability, in the sense of preventing major or drastic downturns. However stability of everything would mean stabilizing things which are already in excess - such as the lifestyles that drive global climate change and generate insecurity for poor people-and stability of 
some things which are in grossly deficient supply. The idea of human security refers instead to attainment or attainability of priority values or basic needs, and not to stabilizing the status quo.

The agenda of clarifying and focusing on basic human values and what threatens or is felt to threaten them has, by an interesting paradox, meant that human security analysis with its apparently restricted focus has sometimes penetrated more deeply than have more open-ended discussions of human development. Mahbub ul Haq, lead author of the global Human Development Reports of 1993 and 1994 that launched the main stream of human security analysis, stressed that by 'human' is meant more than merely the solitary individual, the unit in casualty counts; and correspondingly, exploration of the content of 'human' is required, not only of meanings of 'security' (Lama 2010).

Part of being human is that people have and need meaning systems, including identities. Denis Goulet argued that each person and every society wants to be treated by others for their own sake and on their own terms, as having intrinsic worth regardless of their usefulness to others (Goulet 1975). Human security has essential dimensions that concern felt security, including in how to make sense of one's world, as explored for example in the Chile national report (UNDP 1998) and the UNESCO regional report on Western Europe (Burgess et al. 2007). People's wish and ability to contribute in choosing for themselves and their families has implications for who are the appropriate responders to insecurities; the 'providers', in bureaucratic parlance, should include the people themselves.

\section{Question 4: Which providers?}

Security and insecurity are determined not just by the level of exposure to threats, but by the degree of vulnerability to damage in the face of a given threat, and the extent of resilience, the ability to recover after damage. Hence the policy agenda of human security covers all three areas: exposure, sensitivity and resilience. Many contributors are needed, acting in complementary ways, including to strengthen people's own securitability. Entitlements analysis, elaborated by Amartya Sen and others to understand famines and food insecurity amongst poor and marginal groups (Sen 1981; Dreze and Sen 1991), was then extended to consider more broadly issues of welfare and social security (Dreze and Sen 1989). Such analysis helps to reveal the wide range of factors that affect exposure and vulnerability, and also the wide range of opportunities for counter-action and for strengthening resilience.

Next, the contributors to damage, and hence also potential contributors in remedy, are international as well as intra-national, not only national, especially when we speak of environmental insecurity. In the case of climate change, the Kyoto system's exclusively national framing of issues and of responsibilities has arguably contributed to the global policy deadlock. It has allowed inattention to high-emitters in low-income countries, which has reduced the readiness of high-emitter countries to act (Harris 2010).

Third, human security analyses' focus on issues of basic human needs, including needs for self-expression and self-determination, and frequent anthropological style of attention to real individuals' whole lives and own efforts, have led to emphases on human capability and not only on 
human vulnerability. Empowerment and protection have thus long been equally stressed (CHS 2003; Dreze and Sen 1989, 2002; Gasper 2008). The GECHS research program (1999-2009) came to a definition of human security as where 'individuals and communities have the options necessary to end, mitigate or [sufficiently] adapt to threats to their human, social and environmental rights; have the capacity and freedom to exercise these options; and actively participate in pursuing these options'. Similarly, for Barnett and Adger (2007: 140): 'Human security is taken here to mean the condition where people and communities have the capacity to manage stresses to their needs, rights, and values'; in other words, where they possess adequate securitability. Since people can and should contribute towards their own security, a concern for security is not a language of paternalism; it includes helping people to have the conditions needed so that they can to a large extent act and adapt independently.

\section{Question 6: What are the threats?}

Threats are situation-specific, so there is no fixed universal list of threats. Some scholars try to insist that intentional physical violence is the overwhelming priority threat and the only justified focus for human security studies; MacFarlane and Khong (2006) try to limit the focus even further, to organised intentional physical violence. These are arbitrary attempts to monopolise the concept of human security, that diverge from commonly felt priorities (as we saw for Bangladesh) and from the typical realities of the causation of human insecurity, suffering or deaths (Gasper 2010).

Dangerous global environmental change is underway caused by fossil-fuel intensive lifestyles, which can realistically be called major threats to human security (Dalby 2009; Urry 2011).

While threats vary, some themes recur. First, many threats have major indirect effects, knock-on effects, after they strike. The vulnerability of coastal mega-cities to extreme weather events, sea-level rise and so forth means the indirect vulnerability of their vast nationwide and worldwide hinterlands (O'Brien and Leichenko 2007, section 5). Although the 2008 Bangladesh human security study found that the felt threats to 'freedom from want' were much greater than those to 'freedom from fear', it warned of important linkages. Not least: 'This research finds that political insecurity lies at the heart of many human security challenges in Bangladesh [...for] it makes it less likely that other insecurities will be adequately addressed by the state.' (Saferworld 2008: ix).

Second, threats combine. Old people are particularly vulnerable in the face of climate change (O'Brien and Leichenko 2007, section 6), especially when this combines with changes in family structure that leave more of them living alone and with changes in public finances or public policy that bring reduced or absent state support. Human security thinking looks thus at the specific intersections of diverse forces in persons' and groups' lives. Leichenko and O'Brien's Double Exposure (2008) shows how abstracted disciplinary discourses can miss these vital combinations and interactions. Much human security analysis adopts, in contrast, a supra-disciplinary perspective that looks at particular people and locations and at the intersecting forces in their lives, and leads to case-specific insights. 'Examining the dynamics of vulnerability among rural households in Zambia, Malawi, and South Africa, Ziervogel et al. [2006] found that different households experienced 
different stresses to be the most important. ... An emphasis on human capabilities and human security draws attention to the differential consequences of climate change for individuals and communities resulting first and foremost from disparities in human development.' (O'Brien and Leichenko 2007: 10 \& 14).

Third, human security analysis highlights a particular type of danger: thresholds beyond which negative effects significantly intensify, even leading to system collapse; for example, in the case of persons, leading to death or highly increased chances of death, as when small children or old people are exposed to exceptional stresses. Fourth, threats also bring opportunities; attention to these and to securitability and resilience is vital to avoid reducing human security thinking to a depressing roll-call of hazards.

Many of the cases concerned lend themselves to scenarios thinking rather than to deterministic projections or sets of statistically securely grounded possible pathways. Trying to think intelligently about possible futures is essential, and calls for enhanced skills in listening and narrative imagination that can identify some of the implications of intersections, thresholds, and knock-on effects.

\section{Thinking about future threats and responses}

Gwynne Dyer remarks that IPCC type climate models and projections have stayed 'well clear of any attempt to describe the political, demographic and strategic impacts of the changes they foresee' (Dyer, 2010:3). Most of the projections by international organisations such as the World Bank have assumed, in effect, that there will be no surprises - which would be the real surprise, for reasons we will come to. They thus fail to become convincing scenarios. Future forms of so-called 'adaptation' will include far more than the peaceful building of dykes. Adaptation, responses to climate change-including to changed variance, more frequent extreme events, particular local climatic and environmental quirks - will include many types of human reaction. If climate scientists and social scientists do not study these possibilities enough, military planners worldwide appear to be busy doing so, as for example in two major American studies already from 2007: National Security and the Threat of Climate Change from the Center for Naval Analysis (CNA, 2007) and The Age of Consequences, from the Center for Strategic and International Studies in Washington DC (Campbell et al., 2007).

The sorts of scenarios that they generate suggest: first, the 'magnification of [the] physical effects by likely political and social responses' (Dyer, 2010:16). Second, 'nonlinear climate change [occasional rapid shifts] will produce nonlinear political events' (Fuerth, 2007:72). And third, unlike 'the kind of approach that is often taken in public policy, which is that you only need to do THIS, and the problem will be solved now and forever', we should instead 'Expect that any solutions you apply are likely to disturb the system, leading to an infinite series of surprises' (interview with Leon Fuerth; at Dyer 2010:21). This third insight matches a narrative approach to futures studies: stories will keep on unfolding, with periodic surprises. 
Reviewing the historical record of human responses to environmental crises, the historian J.R. McNeill notes how troubles beget troubles. Disasters fuel mutual suspicions and religious zeal. People under pressure often get nasty. More elegantly stated: 'Restraint and civility can quickly perish when confronted with imperious necessity. This much has been obvious to observers since Thucydides's analysis of the Corcyran Revolution. .. [Political] reaction to shocks often [in history] took the form of scapegoating minorities and foreigners' (McNeill, 2007:29). In a sister chapter in The Age of Consequences, Gulledge warns against the myth that 'climate change will be smooth and gradual. The history of climate reveals that climate change occurs in fits and starts, with abrupt and sometimes dramatic changes rather than gradually over time' (Gulledge, 2007:37). So, as highlighted also by Fuerth, the social impacts and forms of 'adaptation' too could work out differently than suggested by the smooth curves in the scientific reports.

The Age of Consequences builds three climate scenarios. To start with the least worrying: Scenario 1 traces the impacts of the IPCC's 2007 main projection, through to 2040. 'It is a scenario in which people and nations are threatened by massive food and water shortages, devastating natural disasters, and deadly disease outbreaks. It is also inevitable.' (Podesta and Ogden, 2007:55). The various component crises 'are all the more dangerous because they are interwoven and selfperpetuating' (p.56). Scenario 2 adds the early impacts of the dangerous feedback effects that were explicitly not included by the IPCC 2007 Report on the grounds that it was not able to model them for example the danger that the carbon embedded in Siberian permafrost ('more than currently resides in the atmosphere'; Woolsey, 2007:83) - will be released as methane due to warmer temperatures, greatly accelerating the greenhouse effect. The scenario envisages warming of 2.6 degrees C by 2040. 'Agriculture becomes essentially nonviable in the dry subtropics' (Fuerth, 2007:71). Human systems worldwide will come under major stress, and 'massive nonlinear events in the global environment will give rise to massive nonlinear societal events' (p.76). Scenario 3 follows this story through to a world in 2100 that is 5.6 degrees $C$ warmer and where the sea level has already risen two metres. One metre may be enough to flood one-third of Bangladesh, we saw. The study traces the possible diverse human impacts of these climate scenarios, as people and organizations react and interact, leading to an infinite series of surprises.

Dyer illustrates such an approach in richer detail, while never claiming that scenarios are predictions. Pakistan, a country of 180 million people, with nuclear weapons, figures prominently. It is already the world's university for armed Islamic militants. A fast growing population of unemployed young men can continue to provide recruits like the perpetrators of the 2008 Mumbai massacres. 2010 saw the extraordinary Pakistan floods, due to exceptional rains apparently related to a La Nina event in the Pacific. The country has the largest contiguous irrigation system in the world, a system that relies on river waters from the Himalayas. The shrinking of the Himalayan glaciers is envisaged to affect Pakistan's winter water supply and to lead to intense tensions with India, from where several of Pakistan's major rivers come.

Bangladesh, a country with a population almost equal to Pakistan's, is even more environmentally vulnerable. Given a combination of historic, current, and impending damage and grievance, security planners worldwide (e.g., Campbell et al., 2007) ponder scenarios in which the 
country becomes a second university for armed militants. Dyer's scenario 5 concerns a Bangladesh subject to ever more frequent and destructive cyclones. Its government finally threatens to 'upload a million tonnes of powdered sulfates into the stratosphere-in order to cut incoming sunlight and drop the global temperature unilaterally-if there were not swift global agreement on doing it by less noxious means' (Dyer 2010: 161-162).

The story form has a number of advantages for considering human trajectories. It provides descriptions that are not only more vivid but in many respects more realistic. Documents like the Stern Review (Stern 2007) and the 2010 World Development Report employ a limited cast of characters: for example, in some analyses just 'developed', 'developing', and 'emerging' countries. They lack specifics, and, related to that, they miss some of the resulting dynamics. Narratives and scenarios bring us to the concrete particularities, the actual strange combinations, contiguities and coincidences that can and do occur. Second, because stories can better respect complexity they are better in giving understanding. A standard piece of advice in interpretive policy analysis is the Goldberg Rule: don't ask people what's the problem, ask them what's the story. In that way one can get deeper, including in identifying the real problems (Forester, 1999). Or one can ask the sister questions, 'How has this issue come into your life?', or 'What did you do when that happened?' (Forester, 2009). People respond not with theory or speculation but with revealing narratives.

Third, stories are sometimes better for prediction. They show human reactions that are both intelligently calculated and emotionally driven; and they do not shy away from considering the interactions between environmental, economic, social and political impacts that are beyond our ability to formally model. The Stern Review when costing possible impacts in rich countries did not include the feedback effects from economic crisis in 'poorer countries who are more vulnerable to climate change..., with increasing pressures for large-scale migration and political instability' (Stern, 2007:139). The Review recognised a whole series of such omissions (pp.169-73) but had no methodology for dealing with them. In contrast, stories help us to think about the diverse potentials of complex interactions and reveal risks, possibilities and opportunities that can otherwise be overlooked. Scenario exercises help people to perceive connections and possibilities that their mental frames, routines and authority structures may normally screen out (Gasper, 2013a). In stories we can consider the highly improbable combinations that could occur and that, if they do occur, would change everything. While any particular such combination is highly improbable, the chance of occurrence of some such world-changing improbable combination is much higher. Yet social science has too little interest in such 'Black Swan' events, argues Nassim Taleb (2010), since it cannot model them. So, fourthly, stories may be better for promoting preparedness even where we cannot predict.

Fifthly, stories can have strengths in promoting ameliorative action, though they also have dangers. In interpretive policy analysis, telling one's story, showing one's reasons, has the potential to establish a party as a recognised actor in the eyes of the other parties, and to provide information and mutual awareness that open up previously unseen possibilities in the mutual relationships (Forester, 1999). Faced with clearly conflicting values espoused by different parties, there is little point in addressing such a conflict head-on. Instead it becomes essential to explore the 
worldview, history and humanity of each of the parties, to create sufficient mutual understanding and acceptance and find enough pragmatic handles to be able to move forward. The stories of one's interlocutors reveal that they are more multi-featured persons than in one's stereotypes. Thus 'when we face value- and identity-based disputes, we need to mine stories, not sharpen debates' (Forester, 2009:71). Telling personal stories is particularly important for global-scale issues (Schaffer \& Smith, 2004), given 'the power of personal narratives to displace stereotypes and expectations' (Forester, 2009:126).

Sixthly, stories and even scenarios can motivate us better. They feel more real and so have advantages in capturing attention, being remembered, and connecting to action. They engage our emotions, which reinforces all those advantages. They bring us closer to the lives and minds of other people, and show us the human significance of abstracted projections and generalized trends (Gasper, 2013a). Through stories we are emotionally educated, made both more knowledgeable and more sensitive in relation to others (Forester 1999, Ch.2). Abstract talk cannot do most of this work.

Much of the climate literature warns however that doomsday scenarios can generate resignation or disbelief and rejection, and strengthen individualist responses, including the seeking of self-esteem through money, image and status. Stories need to move us beyond focussing only on problems: past, present or future. So scenarios planning exercises typically seek to identify plausible desirable paths too. Scenarios work shows how some of the benefits from inclusive story-making at micro-levels can be extended to much greater scales of operation (e.g., Raskin et al., 2002). More study is needed on which types of narrative and scenario may be helpful for which contexts and tasks.

Dyer's climate-wars scenarios lead him to conclude that a form of cosmopolitan egalitarianism would be the only arrangement that could ensure long-term global peace and survival. The only sustainable basis for a 'global deal' will be not a calculation of 'what is the most we need to concede' but a principle that conveys equality of esteem, such as the one propounded by the Global Commons Institute: that 'everybody on the planet is entitled to the same basic personal allocation of greenhouse gas emission rights, and that those who exceed that allocation must compensate those who use less than their allocated amount' (Dyer, 2010:72).

Morally myopic thinking, such as in 'deals' based purely on self-interest, can tend to induce explanatory myopia too. A focus only on one's own interests can be associated with a shortage of attention to, understanding of, and flow of reliable information from other people. It may bring an underrecognition of connections that bind even the strong to the weak in a globalized world. Giddens (2009: 213ff.) notes thus the failure of the Bush-Cheney 'realist' foreign policy regime of brusque use of military and economic power to enforce its own interests. In Friedman (2009)'s view too this testosterone-driven folie de grandeur proved to be the opposite of realism: it reinforced rather than reduced American reliance on imported oil, and boosted often anti-American autocrats and dictators in oil- and gas-exporting states plus Islamism worldwide (Friedman's 1st Law of Petropolitics). Storytelling helps to make this web of connections clearer than regressions alone ever could. 


\section{Conclusion}

A human security approach can help us in thinking about climate change, in various ways. It deepens consideration of connectivity and knock-on effects. It guides us to reflect on the situations of human actors who react to changing pressures and opportunities and are not simply punchbags for greater powers. Damage done to others will spread. Human security analysis may then help to widen the awareness by important elite groups of these global interconnections, and to counteract narrowly self-absorbed stances (Campbell et al. 2007; Moran 2011; Gasper 2012). Ideally, human security analysis can contribute also to increasing sympathetic attention to the difficulties of others, through its consideration of how 'distant others' live and feel and of the global interconnections. It may support the changes that are needed for global sustainability in respect of how people perceive shared vulnerabilities, shared interests, and shared humanity (The Earth Charter; Gasper 2009).

Karen O'Brien and Robin Leichenko's closing summary from their background paper for the 2007/8 Human Development Report provides a good short synthesis:

'climate change has for the most part been perceived, debated, and addressed as an environmental issue, rather than as a human security issue. A human security approach to climate change can be considered a people-oriented approach that emphasizes both equity issues and the growing connectivities among people and places. It focuses on the management of threats to the environmental, social and human rights of individuals and communities, while at the same time enhancing the capacity to respond to both change and uncertainty. Responding to climate change from a human security perspective requires that both mitigation and adaptation strategies consider the equity and connectivity dimensions of human security.' (O'Brien and Leichenko, 2007: 32).

Notwithstanding the importance of connectedness and knock-on effects, the greatest valueadded of human security analysis rests in its equity agenda: less in the warning of damage to the rich than in the insistence on focusing on the rights of the poor. Some authors suggest that the uncertainties about the precise forms and effects of climate change in particular places can make it very difficult to clearly link climate change and human security. Precision and a high degree of certainty are requirements in tort law, for proving that actions by agent $A$ are responsible for damages $D$ to victim $V$. But tort law is not the only relevant mechanism for responding to the global interconnections in which myriads of emitters endanger and harm myriads of vulnerable people dispersed around the world. We have enough precision and certainty in our knowledge of the general connections to justify establishing a system of global social insurance and protection (Penz 2010; Gasper 2012). Further, the uncertainties about exact causes of particular instances of damage - the periodically devastated livelihoods in delta and low-lying areas, for example-make human insecurity more than just an issue of calculable risk. It involves the question of ethical ordering of the responses to such uncertainties and the determination of who should bear or share the costs and the (in the general, informal sense) risks. Human security analysis helps us to look at 
who and which values are being secured, how much attention is given to basic aspects of the lives of vulnerable people. and whose interests are referred to when dealing with risks and uncertainties.

The foremost insecurity is that of vulnerable marginal populations in much of Africa, Asia and Latin America, as well as on islands and in low-lying areas elsewhere (as Hurricane Katrina illustrated). Possible knock-ons to wider destabilization of political and economic systems are more speculative. Whatever the uncertainties regarding the latter there is considerable certainty regarding the former insecurity. The IPCC's recent report on extreme weather shows vividly how the combination of increased average temperatures and increased weather variability will dramatically increase the frequency of very hot weather, as well as more modestly increase the frequency of hot weather, and also affect the frequency of cold and very cold weather. (See diagrams SPM.3; IPCC 2012, p.5.) We know how 'higher temperatures may mean that previously unsuitable areas will become suitable for transmission of vector borne diseases such as malaria' (O'Brien and Leichenko 2007: 10). And the UN advisory group on the ethics of science and technology underlines how 'even a 2 degree rise in average temperatures [a figure that will likely be greatly exceeded during this century] will have catastrophic effects for populations living on small islands, large river deltas, or other low-lying areas' (COMEST 2010: 36).

Barnett et al. when reporting at the end of the GECHS research programme on Global Environmental Change and Human Security concentrate at first on the possible link from environmental change to armed conflict, although this is not the most important impact in human security terms (Barnett et al. 2010: 10-15); indeed the only specific issue to which they give its own section in the book is possible armed conflict. The significance of the nexus between environmental change, including climate change in particular, and violent conflict, lies however not in the presence of a universal high linkage, which does not exist, but in the possibility of conflagration in a few of the numerous potential tinderboxes. And even more important, as cited by Nordas \& Gleditsch (2013, p.8): “Gleick (1998) also argues that, 'for the most part, inequities [in regard to water access] will lead to poverty, shortened lives, and misery, but perhaps not to direct conflict' (p. 113)". Poverty, shortened lives, and misery; the significance of climate change for human insecurity, as opposed to state insecurity, is evident.

The equity and connectivity dimensions in human security thinking are both vital and are interlinked, not accidental partners. Sensitivity to border-crossing connections comes partly through sensitivity to the lives that are affected. Human security thinking combines a normative ontology of the value of human persons, as in human rights work, and an explanatory ontology of interconnectedness (Gasper 2012, 2013a). Much rights thinking has been emphatically individualist and stressed people's dignity alone. But the human rights commitment needs to be embedded in a richer and more realistic understanding of the human species, its vulnerabilities and capabilities, including both its dependence on its habitat and its power now to dangerously destabilize it. A human security framework helps to sustain such an understanding. 


\section{REFERENCES}

Ahmed, F., 2007. Statement by His Excellency Dr. Fakhruddin Ahmed, Honorable Chief Adviser of the Government of the People's Republic of Bangladesh at the High-level Event on Climate Change, New York, 24 September 2007. Cited in Saferworld 2008, p.23.

Barnett, Jon, and W. Neil Adger (2007), 'Climate change, human security and violent conflict', Political Geography 26(2007), 639-655.

Barnett, Jon, Richard A. Matthew, and Karen L. O’Brien (2010) ‘Global Environmental Change and Human Security: An Introduction'. In Global Environmental Change and Human Security, eds. Richard A. Matthew, Jon Barnett, Bryan McDonald, Karen L. O’Brien; Cambridge, MA: MIT Press, pp.3-32.

Brauch, Hans Günter, 2005. Environment and Human Security: Towards Freedom from Hazard Impacts. Bonn: United Nations University Institute for Environment and Human Security.

Burgess, J. Peter, et al., 2007. Promoting Human Security: Ethical, Normative and Educational Frameworks in Western Europe, Paris: UNESCO.

Burton, J.W. (1990) Conflict: Basic Human Needs, New York: St. Martin's Press.

Campbell, Kurt, et al., 2007. The Age of Consequences: The Foreign Policy and National Security Implications of Global Climate Change. Washington, DC: Center for Strategic and International Studies/Center for a New American Security.

CHS /Commission on Human Security (2003) Human Security Now, New York. UN Secretary-General's Commission on Human Security.

CNA, 2007. National Security and the Threat of Climate Change. Alexandria, VA: CNA (Center for Naval Analysis) Corporation.

COMEST, 2010. The Ethical Implications of Global Climate Change. World Commission on the Ethics of Scientific Knowledge and Technology (COMEST), Paris: UNESCO.

Dalby, Simon. 2009. Security and Environmental Change. Cambridge: Polity.

Dalby, Simon. 2013. Climate change as an issue of human security. In M. Grasso \& M. Redclift (eds.), ... Dreze, Jean, and Amartya Sen, 1989, Hunger and Public Action. Oxford: Clarendon.

----2002. India: Development and Participation Oxford: Oxford University Press.

Dreze, Jean, and Amartya Sen (eds.), 1991. The Political Economy of Hunger (3 vols.). Oxford: Clarendon. Dyer, Gwynne, 2010. Climate Wars. Oxford: Oneworld Publications.

Edwards, Alice, and Carla Ferstman (eds., 2011) Human Security and Non-Citizens: Law, Policy and International Affairs (Cambridge: Cambridge University Press).

Earth Charter Initiative. The Earth Charter. http://www.earthcharterinaction.org/content/pages/readthe-charter.html

Forester, John, 1999. The Deliberative Practitioner. Cambridge, MA: MIT Press.

Forester, John, 2009. Dealing with Differences. New York: Oxford University Press.

Friedman, Thomas, 2009. Hot, Flat and Crowded - Release 2.0. New York: Picador.

Fuerth, Leon, 2007. Security Implications of Climate Scenario 2. Pp.71-79 in Campbell et al.

Gasper, Des, 2005. Securing Humanity - Situating 'Human Security' as Concept and Discourse. J. of Human Development, 6(2), 221-245.

Gasper, Des, 2008. From 'Hume's Law' To Policy Analysis For Human Development - Sen after Dewey, Myrdal, Streeten, Stretton and Haq. Review of Political Economy, 20(2), 233-256.

Gasper, Des, 2009: 'Global Ethics and Human Security', pp. 155-171 in Vol. 1 of Globalization and Security: an encyclopedia, eds. G. Honor Fagan \& Ronaldo Munck; Westport, CT: Greenwood.

Gasper, Des, 2010: 'The Idea of Human Security', in K. O’Brien, A. L. St. Clair, B. Kristoffersen (eds.), Climate Change, Ethics and Human Security, Cambridge: Cambridge Univ. Press, pp.23-46.

Gasper, Des, 2011: Denis Goulet. In Encyclopedia of Global Justice, ed. D. Chatterjee; Dordrecht: Springer. Volume 1, pp. 457-459. 
Gasper, Des, 2012: Climate Change - The Need For A Human Rights Agenda Within A Framework Of Shared Human Security. Social Research: An International Quarterly of the Social Sciences, 79(4).

Gasper, Des, 2013a: Climate Change and the Language of Human Security. In Ethics, Policy and Environment, 16(1).

Gasper, Des, 2013b: Concepts of Human Security. In M. Martin and T. Owen (eds.), The Routledge Handbook of Human Security (Routledge).

Gasper, Des, Ana Victoria Portocarrero, and Asuncion St. Clair, 2013a. 'The Framing Of Climate Change And Development: A Comparative Analysis of the Human Development Report 2007/8 and the World Development Report 2010' Global Environmental Change 23 (2013), 28-39.

----, 2013b: An Analysis of the Human Development Report 2011 'Sustainability and Equity: A Better Future for All'. S. African J. of Human Rights.

Giddens, Anthony, 2009. The Politics of Climate Change. Cambridge: Polity.

Gomez, Oscar A., Des Gasper, Yoichi Mine, 2013. Good Practices in Addressing Human Security through National Human Development Reports. Report to Human Development Report Office, UNDP, New York.

Goulet, Denis (1971) The Cruel Choice. Atheneum, New York

Goulet, Denis (1975) The high price of social change - on Peter Berger's 'Pyramids of Sacrifice'. Christianity and Crisis 35(16):231-237.

Gulledge, Jay, 2007. Three Plausible Scenarios of Future Climate Change. Pp.35-53 in Campbell et al. Harris, Paul, 2010. World Ethics and Climate Change. Edinburgh: Edinburgh University Press.

IIHR, n.d. 'What is Human Security?' San Jose, Costa Rica: Inter-American Institute of Human Rights. http://www.iidh.ed.cr/multic/default 12.aspx?contenidoid=ea75e2b1-9265-4296-9d8c3391de83fb42\&Portal=IIDHSeguridadEN.

IPCC, 2007. Fourth Assessment Report. Intergovernmental Panel on Climate Change. http://www.ipcc.ch/ and Cambridge: Cambridge University Press.

IPCC, 2012. Managing The Risks Of Extreme Events And Disasters To Advance Climate Change Adaptation: Summary For Policymakers. Cambridge: Cambridge University Press.

Lama, Mahendra, 2010. Human Security in India. Dhaka: The University Press Ltd.

Leaning, Jennifer, 2008 Human security. In Green M, ed. Risking human security: Attachment and public life. Karnac Books. London.

Leaning J., S. Arie, E. Stites 2004. Human security in crisis and transition. Praxis: The Fletcher Journal of International Development; 19: 5-30.

Leichenko, Robin, and Karen O'Brien, 2008. Environmental Change and Globalization: Double Exposures. New York: Oxford University Press.

MacFarlane, N., and Khong Y.F., 2006. Human Security and the UN - A Critical History, Bloomington, IN:

University of Indiana Press.

McNeill, J.R., 2007. Can History Help Us With Global Warming? Pp.23-33 in Campbell et al.

Moran, Daniel, ed., 2011. Climate Change and National Security: a country-level analysis. Washington, DC: Georgetown University Press.

Nordas, Ragnhild, and Nils Petter Gleditsch, 2013. The IPCC, human security, and the climate-conflict nexus. In this volume.

O’Brien, Karin, and Robin Leichenko, 2007 Human Security, Vulnerability and Sustainable Adaptation Occasional Paper 2007/9, New York: Human Development Report Office, UNDP.

Penz, Peter. 2010. "International ethical responsibilities to 'climate change refugees'." In Climate change and displacement - multidisciplinary perspectives, ed. J. McAdam; 151-174. Oxford: Hart Publishing.

Podesta, J., and Ogden, P., 2007. Security Implications of Climate Scenario 1. Pp. 55-69 in Campbell et al. 
Raskin, Paul; Banuri, T.; Gallopín, G.; Gutman, P.; Hammond, A.; Kates, R.; Swart, R., 2002. Great Transition- The promise and lure of the times ahead. Boston: Stockholm Environment Institute. http://www.gtinitiative.org/documents/Great Transitions.pdf

Roe, P., 2010. Societal Security. In Contemporary Security Studies, ed. A. Collins, 202-217. Oxford: Oxford University Press.

Rothschild, Emma (1995) 'What is Security?'. Daedalus, Vol.124, No.3, 53-98.

Saferworld (2008), Human Security in Bangladesh. London: Saferworld. http://www.isn.ethz.ch/isn/Digital-Library/Publications/Detail/?ots591=0c54e3b3-1e9c-be1e2c24-a6a8c7060233\&lng=en\&id=57361 Pp. 128 \& xvi.

Schaffer, K., and S. Smith, 2004, Human Rights and Narrated Lives: The Ethics of Recognition. New York: Palgrave.

Sen, A.K., 1981. Poverty and Famines. Oxford: Clarendon.

Stern, Nicholas, 2007. The Economics of Climate Change - The Stern Review. Cambridge: Cambridge University Press.

Taleb, Nicholas, 2010. The Black Swan - The Impact of the Highly Improbable. Revised edition. London: Penguin.

Thomashow, Mitchell. 2002. Bringing the Biosphere Home. Cambridge MA: MIT Press.

Truong, Thanh-Dam, and Des Gasper (eds.) 2011. Transnational Migration and Human Security. Heidelberg: Springer.

UNDP 1998. Chile National Human Development Report: Paradoxes of Modernity - Human Security. http://hdr.undp.org/en/reports/national/latinamericathecaribbean/chile/name,2978,en.html

UNDP, 2003. Latvia Human Development Report: 2002-2003: Human Security. http://hdr.undp.org/en/reports/nationalreports/europethecis/latvia/name,3194,en.html

UNDP, 2005. Overcoming Fear: Citizen (In)security and Human Development in Costa Rica http://hdr.undp.org/en/reports/national/latinamericathecaribbean/costarica/costa_rica_2005_en.pdf

UNDP, 2007. 2007/2008 Human Development Report: Fighting climate change: Human solidarity in a divided world. New York: United Nations Development Program.

UNDP 2010. Abrir espacios para la seguridad ciudadana y el desarrollo humano. Central American Human Development Report 2009/10. http://hdr.undp.org/en/reports/regional/latinamericathecaribbean/name,19660,en.html

UNDP, 2011. Human Development Report 2011 - Sustainability and Equity: A Better Future for All. New York: United Nations Development Program.

UNDP 2012. Human Development and the Shift to Better Citizen Security. Caribbean Human Development Report 2012. http://hdr.undp.org/en/reports/regional/latinamericathecaribbean/name,24269,en.html

Urry, John, 2011. Climate Change and Society. Cambridge: Polity.

Woolsey, R.J., 2007. Security Implications of Climate Scenario 3. Pp.81-91 in Campbell et al.

World Bank, 2010. World Development Report 2010: Development and Climate Change. Washington DC: World Bank.

World Bank 2011. World Development Report 2011: Conflict, Security and Development. Washington DC: World Bank.

Ziervogel, G., Taylor, A., Thomalla, F. Takama, T. and C. Quinn. 2006. Adapting to Climate, Water and Health Stresses: Insights from Sekhukhune, South Africa. Stockholm: Stockholm Environment Institute. 